\title{
The activity-based costing model trajectory: A path of lights and shadows
}

\author{
M. Angels Fito ID, Joan LlobetiD, Natalia Cuguero iD \\ UOC (Spain) \\ afitob@uoc.edu,jllobetda@uoc.edu,ncuguero@uoc.edu
}

Received July, 2017

Accepted October, 2017

\section{Abstract}

Purpose: To present a literature review showing the trajectory of the ABC model.

Design/methodology: Literature review.

Findings: This paper analyzes the history of the $\mathrm{ABC}$ model and its dissemination process, in the form of articles published in the specialized press.

Research limitations/implications: The bibliometric study has been carried out based on specialized journals.

Practical implications: Before a new strategic management tool is adopted, its strategic or operational contribution to the organization should be analyzed. The adoption of new tools based on current trends or as part of mimetic processes, could imply financial investments that do not produce the desired effects.

Originality/value: This work is an analysis of the trajectory of the $\mathrm{ABC}$ model from its appearance to the present time.

Keywords: Activity-based costing, Implementation process, Process of dissemination, Cost management tools

Jel Codes: M41, M21

\section{Introduction}

Since it was conceived in 1984 (Kaplan), the ABC costing model has undergone a "boom and bust" cycle that has been researched and questioned by different authors (Malmi, 1997; Gosselin, 1997). During its evolution, it has faced different conceptual challenges that have arisen: production capacity management, the cost allocation hierarchy, and the impact of process management, among others. This evolutionary process has resulted in a new conceptual definition of it which, while simplifying its operability, has also undermined its intended capacity to become, more than just a cost calculation model, a management control model.

It has been precisely the numerous cases of failure in its implementation that have motivated the study of the different aspects surrounding this process that leads to the implementation of the ABC model. Attributing the partial success of the model to the barriers to its adoption and integration, different works have made it possible to identify a set of factors that particularly affect each of the stages that form part of the implementation process (Anderson, 1995; Gosselin, 1997; Krumwiede, 1998). 
After analyzing the vicissitudes that the model has undergone in recent decades, it is possible to determine that the $\mathrm{ABC}$ model has seen its promising process of expansion halted due to both conceptual problems and shortcomings in terms of its definition and difficulties attributed to its implementation process. These two realities, a cost calculation that does not go beyond the limits of a complete cost model, and the difficulties inherent to the process required to implement it effectively, have resulted in a cost-benefit imbalance that would explain its scarce presence in companies today. Reflection on this dissemination process also enables us to draw conclusions about the forces that drive the dissemination of certain business solutions. These forces, which are widely echoed in a global context, but are not always based on the most efficient choice (Malmi, 1999), may be different from what should occur in business management, which would be the very progress in the quest for improvements in management control systems. In this sense, the impact of mimetic processes promoted by professionals and consultants could result in implementations that cannot be justified as the product of a sound business choice.

To contrast these conclusions, which in the case of the $\mathrm{ABC}$ model, would shed doubt upon the model's strategic cost management capacity, the different publications that have appeared have been monitored, primarily in the journal Management Accounting Research (MAR), over a period of three decades. From the analysis of these publications, it is concluded and corroborated that there has been a decrease in interest in the model as compared to the BSC model, which in principle has maintained a constant level of interest by researchers (or as compared to other budget models, which are also a tool used by large, medium and small businesses alike).

The article is structured as follows: the following section analyzes the conceptual evolution of the model, considering the strategic bases that justified it, the main challenges it faced and its evolution up to its latest version or update, referred to as Time-Driven Activity-Based Costing. Section three analyzes the main publications. Section four discusses the main conclusions drawn from the analysis of the previous works and then identifies the works that have been analyzed to write this article.

\section{The conceptual evolution of the $\mathrm{ABC}$ model}

Practically thirty years after it first appeared in the academic community (Kaplan, 1986), we wish to analyze the conceptual evolution of the $\mathrm{ABC}$ model from its emergence until the present day.

\subsection{The strategic fundamentals of $\mathrm{ABC}$}

The link between ABC and strategy can be implicitly found in the work by Porter (1985), when he asks the question "What is strategy?", and states that strategy means creating a singular, valuable position that requires a different set of activities. This positioning based on the concept of unique activities is reinforced by the author himself, who later states that strategy is competing while renouncing certain things in order to reach the main goal (Porter, 1996).This concept of renouncement that gives a new dimension to the term strategy is imposed when the very definition of the strategic position makes it necessary to choose among incompatible activities. In support of the previous position, in a more recent contribution, Porter (1999) explains that strategy consists of creating an optimal fit between the different activities of the company. In this way, the author revisits the concept of the value chain and stresses the need for a synergistic effect among the different activities.

Once the strategic fundamentals inherent to the activity concept have been introduced, the explicit link between the ABC model and Porter's theory of strategic positioning is presented to us by Shank and Govindarajan (1989). The authors, in their desire to definitively link cost and strategy management, determine that the phases that a strategic analysis of the cost incorporates are: defining the value chain and assigning costs and assets in each value activity, investigating the cost drivers that regulate each value activity and examining the possibility of building a sustainable competitive advantage, by either controlling the cost drivers or reconfiguring the value chain. It is through these elements that Shank and Govindarajan constructed a theory explicitly linking cost management to strategic positioning. This theory has since been empirically tested by authors such as Chendall and Langfield (1998b), who empirically analyze the relationship between Porter's two strategic priorities: leadership in terms of costs and differentiation, and provide an answer about which are the different 
management practices that would be applicable to supporting it. In the study, the author demonstrates that the $\mathrm{ABC}$ model is useful to promote the two strategies mentioned.

It is on the basis of this link between strategy and cost management that Johnson and Kaplan (1987) endorse the virtues of the $\mathrm{ABC}$ model, the essence of which is based on the contributions of authors like those just mentioned.

\subsection{Establishing the conceptual bases of the ABC model}

In the beginning, and until it was christened as such, the configuration (more than the appearance) of the model was the product of local research by a group of authors and work networks.

Thus, in the early 1980s, Harvard University hosted a distinguished group of scholars who were concerned about the impact the changes in the economic world order could have on American industry. This context is perfectly portrayed in articles such as The hidden factory by Miller and Vollman (1985), which shows an expectant American industry faced by the opportunities and threats of international competition from Japan, which threatens the relative security of domestic markets with new and revolutionary production techniques (primarily Just in Time and Total Quality Management).

Against this backdrop, Harvard reacts with a position that is later described by some authors as a productivist strategy (Amstrong, 2002), which situates the company's axis of competitive force on its capacity to excel in terms of the productive function. It is in this context that R. Kaplan (1984) communicates his vision of the existing management systems, focusing his critique on three aspects: the abuse of economic profitability (or $\mathrm{ROA}$ ) as a business indicator, the deficiencies of the existing cost systems, and the predominance of the financial mentality in business management. It is at this time, when the Porterian contributions are in full circulation, that a growing interest is noted in the relevance of non-financial indicators and the virtues of a cost model based on the control of cost drivers are outlined (Kaplan, 1984).

It is based on the suspicion that the current cost systems are not suitable for tackling the challenges of the time that three empirical studies are widely disseminated, led by three US scholars who would come to play a leading role in the conception and evolution of the ABC model: Cooper, with the Shrader Bellow Group case; Kaplan, with the John Deere case; and Johnson, with the Weyerhaeuser case. For many, their joint presentation at Harvard University in 1986 represented the birth of the ABC cost model.

On the other hand, and while the opinion of scholars was being consolidated around this newly emerging concept, another larger network, in this case of professionals, Computer-Aided Manufacturing International (CAM-I), took interest in innovation in cost systems. Backed by some of the most powerful industrial organizations in the United States, a new research line was begun, led by Brimson, with the aim of defining a new cost system that is viable and valuable to its members. The result of this definition is Activity Accounting, the purpose of which is "to measure the cost of the resources consumed in carrying out significant business activities" (Berliner \& Brimson, 1988).

Accordingly, in this first delimitation, which would later be consolidated as the $\mathrm{ABC}$ cost model, sustained by academic and professional contributions, the strategic objective of cost reduction and establishing competitive prices takes precedence. This objective, which attacks current cost systems, has its culminating moment with the publication and subsequent repercussions of the work "Relevance Lost. The rise and fall of management accounting" (1987). While in April 1988 there is still talk of the transaction costing system (Cooper \& Kaplan, 1988), months later T. Johnson (1988) would christen it once and for all as Activity Based Costing, consolidating the initials ABC, which will ultimately become the name of this new system. This new system has the challenge of overcoming the deficiencies of the existing cost systems, most of which the authors themselves acknowledge stem from the dependence on direct labor for the cost allocation process.

During the consolidation of the model, the different perspectives of Kaplan and Cooper and of Johnson were maintained; for the former authors, the main concern is a more accurate or realistic measure of the cost, while 
for the latter, the emphasis must be placed on managing activities. The central role Johnson assigns to activities management, where the Porterian references are constant, led to the conception and standardization of the term Activity Based Management and its initials, ABM.

\subsection{Conceptual evolutions of the ABC model}

Later, the so-called "fathers" of the ABC model (Kaplan, 1994) caused it to evolve through conceptual advances in response to limitations detected by other authors.

One of them is E. Goldratt, who offered the theory of limitations, also known as the Theory of Constraints (hereinafter, TOC). In response to the criticism that the $\mathrm{ABC}$ model, like the traditional cost models, assigns products and/or clients costs upon which the company cannot act over the short term, Cooper and Kaplan respond by questioning the empirical validity of this concept of fixed costs sustained by TOC. The authors argue that fixed costs and their management are increasingly what determine the profitability of a product, either because the product mix and the client determine their final amount or because, in any case, these fixed costs have an increasing weight in relation to sales. In spite of the aforementioned differences, the authors validate the hypotheses of TOC (not assigning capacity cost to the products), as long as it limits its application to a very short-term time horizon and recognizing in this sense the limited usefulness of the ABC model when dealing with problems with the short-term programming of those resources that have limitations.

The final result is the revision of the conceptual bases of the model, where the concept of resources is restructured and enriched, on the one hand, incorporating a distinction between the resources used and the resources supplied, and on the other hand, estimating the costs of all the resources, including both those that are flexible and committed. The new version of the $\mathrm{ABC}$ model, which breaks away from the traditional dichotomy between fixed and variable costs, thus considers that most of the costs in an organization are not short-term variables, except for flexible costs, which are the only ones that a company can really acquire as they are needed. Furthermore, committed costs become variable costs over longer periods of time.

Another of the most important modifications in this redefinition of the model is that introduced by Cooper and Kaplan (1991): where, until then, the only costs excluded as relevant for determining the produce cost were excess capacity and those related to $R \& D$ processes, the list of exclusions increases significantly. These exclusions are structured in the cost hierarchy that intends to facilitate for managers the causal relationship that exists between the activities and the resources that they consume. The degree of sophistication of the model has been supported by subsequent empirical studies, such as that by Ittner and Larcker (1997), for example, who validate the correlation that exists between the different levels of this cost hierarchy and their behavior.

The skepticism generated surrounding these changes, for some considered to be rectifications, and the expectations generated in terms of the new management trends, such as process re-engineering, generates doubts about the virtues of the model, and the bases have been redefined on more than one occasion over a very short period of time since their conception. The most noteworthy case, due to the radical nature of his change in position towards the $\mathrm{ABC}$ model, is the change in opinion expressed by T. Johnson, who was previously a firm defender of activities management, but now states that benefits can be derived from the information provided by the cost model (Johnson, 1991). The doubts suggested in this article when it states that "the information coming from the different models improves the confidence in the product cost for strategic decision-making, but it is not, in fact, information on activities," became evident certainties when in 1992 he published the solo work Relevance Regained (Johnson, 1992). The contents of this work were later summarized in an article in which opinions can be found that demonstrate his skepticism regarding whether the ABC model is capable of managing the new challenges that emerge in an increasingly more competitive environment (Johnson, 1992).

Later, in pace with the environmental transformations that promote a new orientation towards process management instead of individually conceived activities, the ABC model was required to tackle new challenges. The management proposal that monopolized this attention in process management is known as Business Process Improvement (christened with the initials BPI), and in light of this new trend, influential authors such as 
T. Johnson, joined by T. Davenport, questioned the capacity of the ABC model to include informational needs in their bases and methods. The response to these criticisms was precisely to add a new and definitive dimension to their approaches: the evaluation of management through the execution of measures of the execution of the activities that meant the definitive incorporation of the initials ABM. This new version of the model, which was a step back from the initial mission of promoting a precise cost calculation, is perfectly set out in the reflection made by Kaplan and Cooper (1999, pp. 108) when they state: "If we had to reintroduce the ABC model once again, the word 'costing' might not be included in its title."

Therefore, with the overlapping of this new dimension to the financial perspective inherent to the cost measurement and control process, we added and gave priority to the evaluation of the execution of the activities, and thus the processes (Turney, 1991). This evaluation opened up a new trend in management based on nonfinancial information, which so far, had only been marginally useful. This information took on a relevance that continues even today, where tools such as the scorecard have seen their existence extended.

It could thus be stated that the successive criticisms of the model have caused it to evolve into a new concept, which stripped of its usefulness for the purposes of cost calculation, finds its raison d'etre sustained in the strategic management of activities. While initially this strategic dimension coexisted with the scorecard, it later found itself absorbed and overcome by it.

Once the conceptual bases are consolidated, and in spite of the criticism received from those who are most skeptical, the dissemination of the ABC cost model turned into a phenomenon with great repercussions in terms of both its geographic scope and its speed of diffusion.

\subsection{The true stumbling block of the $\mathrm{ABC}$ model: Its implementation process}

At first, it could seem that the causes inherent to this explosion are those that justify its very existence, i.e., its efficiency as a system linked to strategic management. However, since the beginning of its expansion, a significant percentage of failures have been attributed to its implementation, with a number of cases having been analyzed and published that reveal a paradoxical situation in which, in spite of the fact that the virtues of the model have been admitted by scholars and professionals (although it has been demonstrated that it also had its detractors), the levels associated with its implementation are not in agreement.

The relevance that this paradox has on the future viability of the model leads us to reconsider the trends of this dissemination in order to determine whether we are faced with a matter associated with the implementation process, or if the dissemination process is the result of other motivations or modes that would explain that its impact is eventually diluted over time.

In line with the work by Abrahamson (1991), which presents the different variables that explain the dissemination and rejection of the innovations in management systems, Malmi (1999) develops a research study that analyzes the elements that have conditioned the expansion of the ABC model throughout the dissemination process up to the end of the millennium. It is efficiency factors, but also modes and mimetic behaviors, which would explain in a different manner the dissemination process of the $\mathrm{ABC}$ model over the years.

In this regard, Abrahamson argues that apparently the position that dominates in the dissemination processes for innovations is what is explained by a selection of the most efficient option, such as what could at first be assumed to guide the dissemination of the ABC model. However, the author elaborates on the argument, alleging that the most efficient option is based on two situations that do not always occur in a real business situation. The first would be that organizations make choices freely and independently. The second is that organizations have a relative certainty about what their objectives are and what management systems would lead them to achieve these objectives.

It is precisely in this context of relative certainty where the forces or pressures come into play that act during the process of globalization or convergence of the management systems. These pressures were studied by Granlund and Lukka (1998) by identifying four drivers of the management accounting convergence that are applicable to 
the case of the $\mathrm{ABC}$ model. These drivers are: economic pressures, regulatory pressures, coercive pressures and finally, mimetic processes. In the case of the $A B C$ model, these mimetic processes would result in, under conditions of uncertainty, companies adopting those models that are the best publicized, because of the proven solvency of some of their ambassadors and in order to gain legitimacy.

According to this premise, an element that would have been decisive in the transmission of new management techniques would be consulting firms, which by basing their business on the implementation of supposedly innovative systems, have served as the propagators of standardized solutions to recurring management problems. Examining this phenomenon of mimesis in greater depth, there are authors who have claimed that management accounting is equally subjected to fashions or trends in opinion that are not always linked to the organization and the effectiveness of their proposals (Shields, 1998; Ittner \& Larcker, 2001). It is precisely Zimmerman (2001), who was later countered by Luft and Shields (2002), who states that the state of empirical research into management accounting makes very meager contributions to knowledge in the field. In this sense, Porter (1999) already warned of the possibility that the changes in management control systems could turn them into simple tools for improving operations.

In the specific case of the ABC model, Malmi (1999) reveals that after the initial stages of the dissemination process of an innovative system (start-up and launch), the mimetic processes are what compel the dissemination process to continue to be carried out. In line with Abrahamson, Malmi identifies four perspectives that can explain the dissemination of the $\mathrm{ABC}$ model: an efficient choice that would occur in response to changes in business conditions, the forced selection, primarily in cases of recommendations by the parent company, and finally, the trends and mimetic processes derived from imitating the models adopted by other companies in the environment or by following the recommendations of consulting and auditing firms. According to this classification, and based on a distinguished group of Finnish companies, the author determined which of the four perspectives have predominated in the implementation processes. While reasons of efficiency were those that best explain the early adoptions, the body of opinion generated by experts regarding the model exerted a noticeable influence on later adoptions. Finally, and for the most recent years analyzed (1993-1995), in which the implementations were generalized, it is here where the processes of imitation of the pioneering companies in the implementation of the model predominated.

In any case, it can be concluded that in spite of the acceptance and generalized dissemination of their theoretical benefits, relatively few companies achieved a level of standardized use and there were relatively frequent studies that highlighted cases where their implementation failed (Argyris \& Kaplan, 1994; Ness \& Cucuzza, 1995; Innes \& Mitchell, 1995; Chendall \& Langfield-Smith, 1998a; Cavero et al., 2002; Montesinos et al., 2004). Given this reality, there are many contributions and diverse causes that have attributed to this lack of dissemination of the model in practice. Therefore, while some mention the lack of substantiality in its application (Gosselin, 1997; Malmi, 1999), others point to its relative importance for decision-making (Innes \& Mitchell, 1995; Innes, Mitchell \& Sinclair, 2000) or the magnitude of the costs associated with its implementation (Malmi, 1997).

In order to be able to identify the real impact of these factors over the course of the process to implement the model, another group of authors has focused on the study of the implementation process itself, dividing it into different stages and determining the critical factors in each phase (Anderson, 1995, 1999; Gosselin, 1997; Krumwiede, 1998). These works, together with the rest of the works that refer to other factors not found in any specific stage or phase, end up compiling a catalog of factors that would explain the numerous cases of failure during implementation. In summary, and considering the contributions made by different authors and works that have analyzed the model implementation process, these factors could be classified as: the individual characteristics of the company, organizational factors, external factors, technological factors, the profile of the tasks carried out and finally, strategic factors.

The figure below shows all those factors that have been identified in previous studies. 


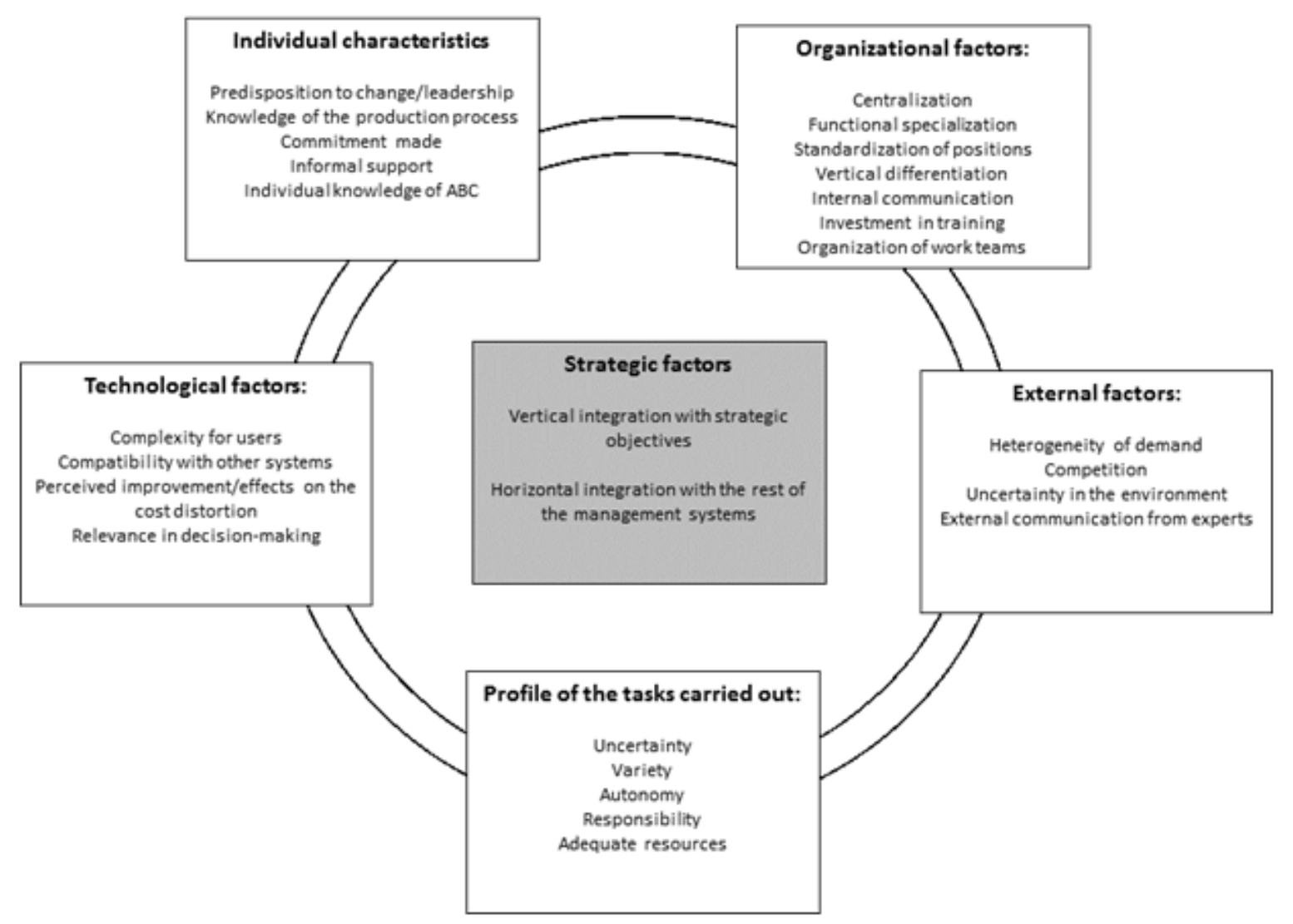

Figure 1. Strategic factors (Fitó, \& Slof, 2011)

\subsection{The latest spin on the ABC model: from the "traditional" ABC model to "Time-Driven Activity- Based Costing"}

The latest, and seemingly final, conceptual spin on the ABC model, has been the appearance of Kaplan's TimeDriven Activity-Based Costing, known by the initials TDABC. It is the father of the original model, Kaplan, who, recognizing the main limitations of the model, particularly with regard to the disproportionate costs of its proper implementation, offers a new simplified version.

Accordingly, in a 2004 article in Harvard Business Review (Kaplan \& Anderson, 2004), the authors, while not completely renouncing the $\mathrm{ABC}$ model, recognize the different barriers that would explain the problems that exist with its implementation. According to the authors, the problems emerge from the manner in which the $\mathrm{ABC}$ model has been constructed within the organizations. In complex organizations, the $\mathrm{ABC}$ model, which the authors already refer to as the traditional $\mathrm{ABC}$ model, requires an estimation to be made of the different cost drivers. An extensive dictionary of activities that requires a periodic measurement that consumes too much time and too many resources, wears down the confidence in the model itself. Therefore, according to the authors, the main problem would be the difficulty in implementation.

In light of this evidence, which was acknowledged in past decades by other authors critical of the model, the authors proposed a solution that they argued would not represent ultimately abandoning the concept of an activity-based model, rather it would be a matter of simplifying it. This simplified version eliminated one of the cost allocation stages, namely the calculation of the cost of each activity, and envisioned assigning costs to different cost objects (transaction, product or client) through a homogeneous cost driver: the capacity time consumed. The solution, which contemplated the different capacity levels used, limited the monitoring to two units of measurement: time and cost, and in this sense, it would detract from the discourse concerning the advantages of having a complete and varied system of non-financial indicators. 
Later, Kaplan himself, in conjunction with Porter, explained the virtues of the model in specific cases of implementation in the area of health (McLaughlin et al., 2014; Helmers \& Kaplan, 2016).

Therefore, in the end, we were faced with a version of the model which, with regard to the problems with its articulation within organizations, renounced some of the principles constituting the cornerstones of its conception. Prioritizing the control and calculation of the costs of the different activities, the cost drivers were limited to one: time, ruling out other cost drivers that might have been relevant. The BSC model managed to incorporate the strategic value of non-financial indicators. The concatenation of these indicators, organized into different perspectives, through cause-effect relationships, became an instrument of strategic management for organizations that still remained present in the specialized press and that targeting professionals.

\section{The history of the $\mathrm{ABC}$ model in publications}

In the previous sections, we have analyzed the previous literature to show how the $\mathrm{ABC}$ cost model, which was created with the aim of helping companies in the process of adapting to environmental challenges, racked up criticisms and misgivings in its dissemination process. In light of this situation, characterized as paradoxical by different authors, a track record has been established through the different studies that have attempted to determine either the keys to its success or the causes for failure in its implementation. While the works present different focuses and differing results, it seems that the lack of substantiality is the greatest determining factor in its decline.

\begin{tabular}{|c|c|c|c|c|}
\hline Journal title & Abbreviation & Starting year & Articles & \\
\hline Management Accounting Research & MAR & 1990 & 48 & $27 \%$ \\
\hline Journal of Management Accounting Research & JMAR & 1989 & 0 & $0 \%$ \\
\hline Accounting and Business Research & $\mathrm{ABR}$ & 1970 & 1 & $1 \%$ \\
\hline Accounting Organization and Society & AOS & 1976 & 18 & $10 \%$ \\
\hline British Accounting Review & BAR & 1988 & 8 & $5 \%$ \\
\hline Journal of Business Finance and Accounting & JBFA & & 1 & $1 \%$ \\
\hline The Accounting Review & TAR & 1926 & 9 & $5 \%$ \\
\hline Journal of Accounting Research & JAR & 1963 & 5 & $3 \%$ \\
\hline Journal of Accounting and Economics & JAE & 1979 & 1 & $1 \%$ \\
\hline Accounting Horizon & $\mathrm{AH}$ & 1987 & 10 & $6 \%$ \\
\hline Journal of Accounting Literature & & & 7 & $4 \%$ \\
\hline Critical Perspectives in Accounting & CPA & 1990 & 5 & $3 \%$ \\
\hline ABACUS & ABACUS & 1965 & 3 & $2 \%$ \\
\hline Accounting \& Finance & $\mathrm{A} \& \mathrm{~F}$ & 1960 & 3 & $2 \%$ \\
\hline Accounting auditing \& accountability journal & AAAJ & 1988 & 1 & $1 \%$ \\
\hline Advances in Accounting & ADIC & 1984 & 3 & $2 \%$ \\
\hline Behavioral Research in Accounting & BRIA & 1989 & 3 & $2 \%$ \\
\hline Contemporary Accounting Research & CAR & 1984 & 1 & $1 \%$ \\
\hline European Accounting Review & EAR & 1992 & 17 & $10 \%$ \\
\hline Financial Accountability and Management & FAM & 1985 & 0 & $0 \%$ \\
\hline Issues in Accounting Education & IIAEd & 1983 & 17 & $10 \%$ \\
\hline Journal of Accounting auditing and Finance & JAAF & 1986 & 1 & $1 \%$ \\
\hline Journal of Accounting Education & JAE & 1982 & 8 & $5 \%$ \\
\hline Journal of Accounting and Public Policy & JAPP & 1982 & 1 & $1 \%$ \\
\hline Review of Accounting Studies & RAS & 1996 & 1 & $1 \%$ \\
\hline The International Journal of Accounting & TIJA & 1996 & 3 & $2 \%$ \\
\hline Total articles & & & 175 & \\
\hline
\end{tabular}

Table 1.Articles on ABC published in accounting journals 
Below, in order to contribute to the knowledge on these nearly three decades of history characterized by mixed results, we analyze the publications that have appeared, highlighting the publications in Management Accounting Research (MAR) magazine, as it is understood that the restriction imposed contributes homogeneity to the analysis. The publications in the MAR have been analyzed, as out of a group of 25 accounting journals, all wellpositioned on the different lists of publications (ABS, JCR), it is the leading academic journal, as it gathers the largest number of articles on the $\mathrm{ABC}$ model.

Table 1 shows the frequencies of the articles found in the scientific accounting journals.

\subsection{Frequency of articles published on the ABC and the BSC models in the MAR}

\begin{tabular}{|l|r|r|r|r|r|r|}
\cline { 2 - 7 } & $\mathbf{1 9 9 0 - 1 9 9 6}$ & $\mathbf{1 9 9 7 - 2 0 0 1}$ & $\mathbf{2 0 0 2 - 2 0 0 6}$ & $\mathbf{2 0 0 7 - 2 0 1 1}$ & $\mathbf{2 0 1 2 - 2 0 1 6}$ & \multicolumn{1}{c|}{ TOTAL } \\
\hline TOTAL ABC & $\mathbf{1 5}$ & $\mathbf{1 7}$ & $\mathbf{8}$ & $\mathbf{6}$ & $\mathbf{2}$ & $\mathbf{4 8}$ \\
\hline TOTAL BSC & $31.25 \%$ & $35.42 \%$ & $16.67 \%$ & $12.50 \%$ & $4.17 \%$ & $\mathbf{0}$ \\
\hline & & $\mathbf{4}$ & $\mathbf{1 0}$ & $\mathbf{1 0}$ & $\mathbf{1 2}$ & $\mathbf{3 6}$ \\
\hline
\end{tabular}

Table 2. Distribution of the frequency of articles published on the ABC and the BSC models in the MAR

Strictly considering the volume of articles published, it is immediately evident that the boom for the model is concentrated practically in the first decade, as the period between 1990 and 2001 accumulates $66.67 \%$ of the articles. In the subsequent periods, the publications gradually decrease until becoming practically non-existent during the last five years analyzed.

If we compare this history to that of another strategic management model, such as the BSC, which appeared a few years later (1992), but which has frequently been paired with the ABC model in its dissemination process, we can see how in the latter case, the frequency in the number of publications is more consistent.

\subsection{Research topics}

\begin{tabular}{|c|c|c|c|c|c|c|c|}
\hline Topic/years & 1990-1996 & $1997-2001$ & $2002-2006$ & 2007-2011 & $2012-2016$ & TOTAL & $\%$ \\
\hline Dissemination of the $\mathrm{ABC}$ & 7 & 4 & 2 & & 2 & 15 & $31.25 \%$ \\
\hline Adoption/implementation & 4 & 5 & 2 & 1 & & 12 & $25.00 \%$ \\
\hline Uses in decision making & 4 & 3 & & 1 & & 8 & $16.67 \%$ \\
\hline Reviews and critical analysis & & 3 & & 3 & & 6 & $12.50 \%$ \\
\hline Organizational effectiveness & & 2 & 4 & 1 & & 7 & $14.58 \%$ \\
\hline
\end{tabular}

Table 3. Frequency in the distribution of articles on the ABC model published in the MAR, by topic

Table 3 shows the distribution frequency of the topics published in connection with the $\mathrm{ABC}$ model during the study period. The dissemination of the model $(31.25 \%)$ and the adoption or implementation of the model $(25.00 \%)$ are the most commonly addressed topics. Regardless of whether they analyze the patterns of dissemination or the factors that affect the implementation processes, it is precisely these articles that attempt to respond to the paradox described in the previous sections. The use of $\mathrm{ABC}$ in decision-making (16.67\%), and its organizational efficiency $(14.58 \%)$ have also been subject to study, in order to demonstrate their function as strategic tools.

\subsection{Research setting}

To the contrary of what might be imagined, most of the articles on the $\mathrm{ABC}$ model that have made mention of a specific sector have done so in the private services sector $(52.08 \%)$. They are followed by articles that make no mention of any specific sector $(33.33 \%)$, and only $6.25 \%$ refer to the industrial sector. Companies in the public sector and not-for-profit organizations have also been subject to analysis in relation to the implementation of the ABC model. 


\begin{tabular}{|c|c|c|c|c|c|c|c|}
\hline Research settings/years & 1990-1996 & $1997-2001$ & $2002-2006$ & $2007-2011$ & 2012-2016 & TOTAL & $\%$ \\
\hline Private services sector & 6 & 9 & 6 & 3 & 1 & 25 & $52.08 \%$ \\
\hline Other & 7 & 6 & & 2 & 1 & 16 & $33.33 \%$ \\
\hline Manufacturing & 2 & 1 & & & & 3 & $6.25 \%$ \\
\hline Public services sector & & 1 & 1 & & & 2 & $4.17 \%$ \\
\hline Not-for-profit/government & anizations & & 1 & 1 & & 2 & $4.17 \%$ \\
\hline
\end{tabular}

Table 4. Frequency in the distribution of articles on the ABC model published in the MAR, by sector

\subsection{Research method}

\begin{tabular}{|c|c|c|c|c|c|c|c|}
\hline Research method/years & $1990-1996$ & $1997-2001$ & $2002-2006$ & 2007-2011 & 2012-2016 & TOTAL & $\%$ \\
\hline Action research & 1 & 1 & & & & 2 & $4.17 \%$ \\
\hline Analytic & 1 & 1 & & & & 2 & $4.17 \%$ \\
\hline Archival & 2 & 4 & & 2 & & 8 & $16.67 \%$ \\
\hline Case/field study & 4 & 5 & 3 & 1 & & 13 & $27.08 \%$ \\
\hline Review & 3 & 1 & & & 1 & 5 & $10.42 \%$ \\
\hline Survey & 4 & 5 & 5 & 3 & 1 & 18 & $37.50 \%$ \\
\hline
\end{tabular}

Table 5. Frequency of the distribution of articles on the ABC model published in the MAR, by research method

The data shown in Table 5 reveal that surveys have been the most commonly used method, with 18 of the 48 articles analyzed (37.5\%).Next are case studies, with 13 articles (27.08\%). These two methods account for almost $65 \%$ of the articles analyzed. In the case of surveys, they have been used on several occasions to analyze the barriers that can condition the implementation of the model, and case studies have illustrated both the virtues of the model, with successful implementations, and difficulties in its implementation, with failed adoptions.

\subsection{Country}

\begin{tabular}{|c|c|c|c|c|c|c|c|}
\hline $\begin{array}{l}\text { Primary data } \\
\text { analysis/years }\end{array}$ & 1990-1996 & 1997-2001 & 2002-2006 & 2007-2011 & 2012-2016 & TOTAL & $\%$ \\
\hline UK & 5 & 4 & 1 & 1 & & 11 & $22.92 \%$ \\
\hline Scotland & 3 & 2 & 1 & & & 6 & $12.50 \%$ \\
\hline USA & 3 & 1 & 2 & & & 6 & $12.50 \%$ \\
\hline Australia & & 2 & 2 & & & 4 & $8.33 \%$ \\
\hline Netherlands & 1 & & 1 & 1 & & 3 & $6.25 \%$ \\
\hline Finland & & 1 & & 1 & 1 & 3 & $6.25 \%$ \\
\hline Germany & & 3 & & & & 3 & $6.25 \%$ \\
\hline New Zealand & 1 & 1 & & & & 2 & $4.17 \%$ \\
\hline Norway & & 2 & & & & 2 & $4.17 \%$ \\
\hline Sweden & & & & 1 & 1 & 2 & $4.17 \%$ \\
\hline Austria & 1 & & & & & 1 & $2.08 \%$ \\
\hline Japan & 1 & & & & & 1 & $2.08 \%$ \\
\hline Canada & & 1 & & & & 1 & $2.08 \%$ \\
\hline Portugal & & & 1 & & & 1 & $2.08 \%$ \\
\hline Belgium & & & & 1 & & 1 & $2.08 \%$ \\
\hline France & & & & 1 & & 1 & $2.08 \%$ \\
\hline
\end{tabular}

Table 6. Frequency of the distribution of articles on the ABC model published in the MAR, by country of the author 
As seen in Table 6, which shows the articles according to the country of their authors, Anglo Saxon countries are those with the largest number of publications. Great Britain, the United States and Australia concentrate almost half of the articles published $(47.92 \%)$, while practically all the rest are from Northern Europe. This pattern coincides with the dissemination processes of the proposals that are made in the different locations. While in the United States, the country of origin of the model, more theoretical and analytic studies predominate, in the rest of the countries that import the innovation, such as Great Britain or Northern Europe, surveys, reviews of previous works and case studies predominate in the published works.

\section{Conclusions and lessons learned: Comparison to other phenomena, such as the BSC}

From the specific analysis of the articles published in the MAR journal, we can draw other more qualitative conclusions, such as the following:

- From the beginning, the model has been associated with improved control over production costs (Scarbrough, Nanni \& Sakurai, 1991; Bromwich \& Hong, 1999), while during the same period, other opposing works have praised the model for its strategic capacity for cost management (Mitchell, 1994), and some articles have emphasized its lack of relevance or contribution to existing complete cost models (Staubus, 1990; Bright, Davies, Downes \& Sweeting, 1992). Some of these studies already indicated that mimetic phenomena can lead to poor dissemination of the model.

- It is also common to find studies that revealed the need for more empirical evidence, normally in the form of case studies, that would make it possible to do away with the doubts generated by its implementation process (Gietzmann, 1991; Spicer, 1992). These works, along with those by Kaplan himself (1994), warned about the need for exploratory studies and field work that would enable us to consolidate the theoretical advances made.

- In response to the need to link theory and practice and in order to give the proposed model greater robustness, different works also provided results on the study of specific implementation processes (Bhimani \& Pigott, 1992). While each of the works approached the implementation process from a different perspective, the final objective coincided to a large extent in identifying the factors that determined the correct implementation of the model. From this line of work, the study by Malmi (1997) stands out, which specifically contrasted cases of success and failure.

- Also with the purpose of providing more evidence that resolves the paradoxical situation of the model in which the theoretical and practical dissemination follow very different paths, there are works that have studied the factors determining the decision to adopt or not to adopt the model as a management tool (Innes \& Mitchell, 1995, 1997; Cobb, Helliar \& Innes, 1995). Some of these works have sought these determining factors in internal matters, such as product diversity (Abernethy, Lillis, Brownell \& Carter, 2001), team characteristics (Soin, Seal \& Cullen, 2002) and organizational factors (Baird, Harrison \& Reeve, 2004; Kallunki \& Silvola, 2008; Ax \& Greve, 2016), while others have done so according to variables related to the national culture (Brewer, 1998). Some of these studies have made it possible to analyze the dissemination process in order to determine the forces that have promoted it (Bjørnenak, 1997; Bjørnenak \& Olson, 1999; Englund \& Gerdin, 2008).

- Another set of studies has attempted to establish connections between the ABC model and other strategic management tools, such as the BSC. Part of these studies have compared the dissemination patterns (Kaplan, 1994; Wiersma, 2009) in order to establish when and how these academic findings are consolidated in the business context. In other studies, the ABC model is simply another example used to illustrate the extent to which the new solutions for strategic management of organizations advance research in the area of management accounting (Horngren, 1995; Alcouffe, Berland \& Levant, 2008).

- To demonstrate whether this dissemination process has been unequal according to country or sector, different studies have specifically analyzed the status of the implementation of the model in certain geographic areas, such as Germany (Boons, Roberts \& Roozen, 1992; Kloock \& Schiller, 1997), the 
United Kingdom (Innes et al., 2000; al-Omiri \& Drury, 2007), Canada (Macintosh, 1998), Australia (Chendall \& Langfield-Smith, 1998b) and Portugal (Major \& Hopper, 2005), or in specific sectors, such as telecommunications (Bromwich \& Hong, 2000; Major \& Hopper, 2005) or the public sector (Lapsley \& Wright, 2004).

- Other studies have analyzed the achievements derived from the implementation of the model. These successes or positive consequences can be related to improved financial results (Cagwin \& Bouwman, 2002) or better information (Dekker, 2003).

- Later studies emphasized the hazards of a design based on an excessive diverse cost number (Homburg, 2001). These studies would corroborate the appropriateness of a new version of the model, TimeDriven Activity-Based Costing, which, by drastically reducing the diverse cost number, facilitates the implementation of the model to a great extent (Hoozée \& Bruggerman, 2010).

At the end of this review of the works published in the MAR journal on the ABC model, we can observe how, from the beginning, both drivers and detractors have existed throughout the history of this model. These studies have alerted to the need for more field studies to certify its validity in business contexts. The analysis of the implementation process and the factors that can determine its success and failure have also been subject to study. These doubts surrounding its virtues have been the trigger for other works that have analyzed its patterns of dissemination, as well as its effectiveness in other geographic or sectoral contexts. Finally, works should be highlighted that have analyzed the latest version of the model, which simplifies its design and implementation.

In the end, in light of the diminishing academic interest in the model and its scarce presence in business contexts, we can conclude that the ABC model has not been able to overcome the conceptual and operational shortcomings referred to by authors throughout its more than thirty-year history.

\section{Declaration of Conflicting Interests}

The authors declared no potential conflicts of interest with respect to the research, authorship, and/or publication of this article.

\section{Funding}

The authors received no financial support for the research, authorship, and/or publication of this article.

\section{References}

Abernethy, M.A., Lillis, A.M., Brownell, P., \& Carter, P. (2001). Product diversity and costing system design choice: field study evidence. Management Accounting Research, 12(3), 261-279.

https://doi.org/10.1006/mare.2001.0168

Abrahamson, E. (1991). Managerial fads and fashions: The diffusion and refection of managerial innovations. Academy of Management Review, 16(3), 586-612. https://doi.org/10.5465/AMR.1991.4279484

Alcouffe, S., Berland, N., \& Levant, Y. (2008). Actor-networks and the diffusion of management accounting innovations: A comparative study. Management Accounting Research, 19(1), 1-17.

https://doi.org/10.1016/j.mar.2007.04.001

Al-Omiri, M., \& Drury, C. (2007). A survey of factors influencing the choice of product costing systems in UK organizations. Management Accounting Research, 18(4), 399-424. https://doi.org/10.1016/j.mar.2007.02.002

Amstrong, P. (2002). The Cost of Activity-Based Management. Accounting, Organization and Society, 27, 99-120. https://doi.org/10.1016/S0361-3682(99)00031-8

Anderson, S.A (1995). Framework for Assessing Cost Management System Changes: The Case of Activity-Based Costing Implementation al General Motors 1. Journal of Management Accounting Research, 7, 363-387. 
Anderson, S., \& Young, M. (1999). The Impact of Contextual and Process Factors on the Evaluation of Activity-Based Costing Systems. Accounting, Organization and Society, 24, 525-559.

https://doi.org/10.1016/S0361-3682(99)00018-5

Argyris, C., \& Kaplan, R. (1994). Implementing New Knowledge: The Case of Activity-Based-Costing. Accounting Horizons, 8, 83-105.

Ax, C., \& Greve, J. (2016). Adoption of management accounting innovations: Organizational culture compatibility and perceived outcomes. Management Accounting Research, 34, 59-74.

https://doi.org/10.1016/j.mar.2016.07.007

Baird, K.M., Harrison, G.L., \& Reeve, R.C. (2004). Adoption of activity management practices: A note on the extent of adoption and the influence of organizational and cultural factors. Management Accounting Research, 15(4), 383-399. https://doi.org/10.1016/j.mar.2004.07.002

Berliner, C., \& Brimson, J.A. (1988). Cost management for today's advanced manufacturing: The CAM-I conceptual design. Harvard Business School Press.

Bhimani, A., \& Pigott, D. (1992). Implementing ABC: A case study of organizational and behavioural consequences. Management Accounting Research, 3(2), 119-132. https://doi.org/10.1016/S1044-5005(92)70007-9

Bjørnenak, T. (1997). Diffusion and accounting: The case of ABC in Norway. Management Accounting Research, 8(1), 3-17. https://doi.org/10.1006/mare.1996.0031

Bjornenak, T., \& Mitchell, F. (2002). The Development of Activity-Based Costing Journal Literature, 1987-2000. The European Accounting Review, 11, 481-508. https://doi.org/10.1080/0963818022000001019

Bjørnenak, T., \& Olson, O. (1999). Unbundling management accounting innovations. Management Accounting Research, 10(4), 325-338. https://doi.org/10.1006/mare.1999.0110

Boons, A.A.M., Roberts, H.J.E., \& Roozen, F.A. (1992). Contrasting activity-based costing with the German/Dutch cost pool method. Management Accounting Research, 3(2), 97-117. https://doi.org/10.1016/S10445005(92)70006-7

Brewer, P.C. (1998). National culture and activity-based costing systems: a note. Management Accounting Research, 9(2), 241-260. https://doi.org/10.1006/mare.1998.0077

Bright, J., Davies, R.E., Downes, C.A., \& Sweeting, R.C. (1992). The deployment of costing techniques and practices: A UK study. Management Accounting Research, 3(3), 201-211. https://doi.org/10.1016/S10445005(92)70011-0

Bromwich, M., \& Hong, C. (1999). Activity-based costing systems and incremental costs. Management Accounting Research, 10(1), 39-60. https://doi.org/10.1006/mare.1998.0102

Bromwich, M., \& Hong, C. (2000). Costs and regulation in the U.K. telecommunications industry. Management Accounting Research, 11(1), 137-165. https://doi.org/10.1006/mare.1999.0124

Cagwin, D., \& Bouwman, M.J. (2002). The association between activity-based costing and improvement in financial performance. Management Accounting Research, 13(1), 1-39. https://doi.org/10.1006/mare.2001.0175

Cavero, J. et al. (2002). Barreras para la implantación de un modelo ABC. Revista Española de Financiación y Contabilidad, 113, 861-880.

Chendall, R., \& Langflied-Smith, K. (1998a). The relationship Between Strategic Priorities, Management Techniques and Management Accounting: An Emprical Investigation Usin. Accounting, Organization and Society, 23, (1998a), 243-264. https://doi.org/10.1016/S0361-3682(97)00024-X

Chendall, R., \& Langfield-Smith, K. (1998b). Adoption and Benefits of Management Accounting Practices: An Australian Study. Management Accounting Research, 9, 1-19. https://doi.org/10.1006/mare.1997.0060

Cobb, I., Helliar, C., \& Innes, J. (1995). Management accounting change in a bank. Management Accounting Research, 6(2), 155-175. https://doi.org/10.1006/mare.1995.1009 
Cooper, R., \& Kaplan, R. (1988). How Accounting Distorts Products Cost. Management Accounting, April, 20-27.

Cooper, R., \& Kaplan, R. (1991). Profit priorities from Activity-Based-Costing. Harvard Business Review, May-June, $130-135$.

Cooper, R., \& Kaplan, R. (1999). Coste y Efecto: Como usar el ABC, el ABM y el ABB para mejorar la Gestión, los procesos y la rentabilidad. Ediciones Gestión 2000. ISBN: 9788480882781

Dekker, H.C. (2003). Value chain analysis in interfirm relationships: A field study. Management Accounting Research, 14(1), 1-23. https://doi.org/10.1016/S1044-5005(02)00067-7

Dugdale, D., \& Jones, T.C. (1997). How many companies use ABC for stock valuation? A comment on Innes and Mitchell's questionnaire findings. Management Accounting Research, 8(2), 233-240.

https://doi.org/10.1006/mare.1996.0043

Englund, H., \& Gerdin, J. (2008). Transferring knowledge across sub-genres of the ABC implementation literature. Management Accounting Research, 19(2), 149-162. https://doi.org/10.1016/j.mar.2008.01.002

Fitó Bertran, A, \& Slof, J. (2011). Del diseño de modelos de costes basados en las actividades a su uso normalizad. Intangible Capital, 7(2), 474-506.

Gietzmann, M. (1991). Implementation issues associated with the construction of an activity-based costing system in an engineering components manufacturer. Management Accounting Research, 2(3), 189-199. https://doi.org/10.1016/S1044-5005(91)70034-6

Gosselin, M. (1997). The Effect of Strategy and Organizational Structure on the Adoption and Implementation of Activity-Based- Costing. Accounting, Organization and Society, 22, 105-122. https://doi.org/10.1016/S03613682(96)00031-1

Granlund, M., \& Lukka, K. (1998). It's a Small World of Management Account Practices. Journal of Management Accounting Research, 10, 153-173.

Helmers, R.A., \& Kaplan, R.S. (2016). TDABC in primary care: results of a Harvard/Mayo Clinic collaboration: A partnership between Mayo Clinic and Harvard Business School brought a costing method developed for manufacturing into a primary care setting, helping identify areas for greater efficiency. Healthcare Financial Management, July 2016, 34+.

Hesford, J.W., Dittman, D.A., \& Potter, G. (2009). Managerial Accounting in the Hospitality Industry. Handbooks of Management Accounting Research, 3, 1353-1369. https://doi.org/10.1016/S1751-3243(07)03008-8

Homburg, C. (2001). A note on optimal cost driver selection in ABC. Management Accounting Research, 12(2), 197-205. https://doi.org/10.1006/mare.2000.0150

Hoozée, S., \& Bruggeman, W. (2010). Identifying operational improvements during the design process of a timedriven ABC system: The role of collective worker participation and leadership style. Management Accounting Research, 21(3), 185-198. https://doi.org/10.1016/j.mar.2010.01.003

Hoque, Z. (2014). 20 years of studies on the balanced scorecard: trends, accomplishments, gaps and opportunities for future research. The British accounting review, 46(1), 33-59.

https://doi.org/10.1016/j.bar.2013.10.003

Horngren, C.T. (1995). Management accounting: this century and beyond. Management Accounting Research, 6(3), 281-286. https://doi.org/10.1006/mare.1995.1019

Innes, J., \& Mitchell, F. (1995). A survey of activity-based costing in the U.K.'s largest companies. Management Accounting Research, 6(2), 137-153. https://doi.org/10.1006/mare.1995.1008

Innes, J., \& Mitchell, F. (1997). Survey research on activity-based costing: a reply to Dugdale and Jones. Management Accounting Research, 8(2), 241-249. https://doi.org/10.1006/mare.1996.0042 
Innes, J., Mitchell, F., \& Sinclair, D. (2000). Activity-based costing in the U.K.'s largest companies: A comparison of 1994 and 1999 survey results. Management Accounting Research, 11(3), 349-362.

https://doi.org/10.1006/mare.2000.0135

Ittner, C., \& Larcker, D. (1997). The Activity Based Cost Hierarchy, Production Policies and Firm Profitability. Journal of Management Accounting Research, 9, 142-162.

Ittner, C., \& Larcker, D. (2001). Assessing Empirical Research in Managerial Accounting: A Value Based Management Perspective. Journal of Accounting and Economics, 30, 349-410. https://doi.org/10.1016/S01654101(01)00026-X

Johnson, T. (1988). Activity Based Information: A Blueprint for World-class Management Accounting. Management Accounting, June(1988), 23-30.

Johnson, T. (1991). Activity-Based Management: Past Present and Future. The Engineering Economist, 36, 219-238. https://doi.org/10.1080/00137919108903046

Johnson, T. (1992). It's Time to Stop Overselling Activity Based Concepts: Start Focusing on Costumer Satisfaction Instead. Management Accounting, setembre, 26-35.

Johnson, H.T., \& Kaplan, R.S. (1987). The Rise and Fall of Management Accounting IEEE Engineering Management Review, 15(3), 36-44.

Kallunki, J.-P., \& Silvola, H. (2008). The effect of organizational life cycle stage on the use of activity-based costing. Management Accounting Research, 19(1), 62-79. https://doi.org/10.1016/j.mar.2007.08.002

Kaplan, R. (1984). Yesterdays Accounting Undermines Production. Harvard Business Review, July-August, 95-101.

Kaplan, R. (1986). The Role of Empirical Research in Management Accounting. Accounting, Organization and Society, 11, 429-452. https://doi.org/10.1016/0361-3682(86)90012-7

Kaplan, R.S. (1994). Management accounting (1984-1994): Development of new practice and theory. Management Accounting Research, 5(3), 247-260. https://doi.org/10.1006/mare.1994.1015

Kaplan, R, \& Norton, D. (2004). Measuring the strategic readiness of intangible assets. Harvard business review, February 2004 online version.

Kloock, J., \& Schiller, U. (1997). Marginal costing: Cost budgeting and cost variance analysis. Management Accounting Research, 8(3), 299-323. https://doi.org/10.1006/mare.1996.0048

Krumwiede, K. (1998). The Implementation Stages of Activity-Based-Costing and the Impact of Contextual and Organization Factors. Journal of Management Accounting Research, 10, 239-277.

Lapsley, I., \& Wright, E. (2004). The diffusion of management accounting innovations in the public sector: A research agenda. Management Accounting Research, 15(3), 355-374. https://doi.org/10.1016/j.mar.2003.12.007

Luft, J., \& Shields, M. (2002). Zimmerman's Contentious Conjectures: Describing the Present and Prescribing the Future of Empirical Management Accounting Research. The European Accounting Review, 11, 795-303. https://doi.org/10.1080/0963818022000047091

Macintosh, N.B. (1998). Management accounting in Europe: A view from Canada. Management Accounting Research, 9(4), 495-500. https://doi.org/10.1006/mare.1998.0087

Major, M., \& Hopper, T. (2005). Managers divided: Implementing ABC in a Portuguese telecommunications company. Management Accounting Research, 16(2), 205-229. https://doi.org/10.1016/j.mar.2005.01.004

Malmi, T. (1997). Towards explaining activity-based costing failure: Accounting and control in a decentralized organization. Management Accounting Research, 8(4), 459-480. https://doi.org/10.1006/mare.1997.0057

Malmi, T. (1999). Activity Based Costing Diffusion Across Organizations: An Exploratory Empirical Analysis of Finish Firms. Accounting, Organization and Society, 24, 649-672. https://doi.org/10.1016/S0361-3682(99)00011-2 
McLaughlin, N., Burke, M.A., Setlur, N.P., Niedzwiecki, D.R., Kaplan, A.L., Saigal, C. et al. (2014). Time-driven activity-based costing: A driver for provider engagement in costing activities and redesign initiatives. Neurosurgical focus, 37(5), E3. https://doi.org/10.3171/2014.8.FOCUS14381

Miller, J., \& Vollmann, T. (1985). The hidden factory. Harvard Business Review, setembre-octubre, 142-150.

Mitchell, F. (1994). A commentary on the applications of activity-based costing. Management Accounting Research, 5(3), 261-277. https://doi.org/10.1006/mare.1994.1016

Montesinos, V. et al. (2004). Estudio sobre implantación de la contabilidad de gestión en España. Revista Iberoamericana de Contabilidad de Gestión, 2, 177-238.

Ness, J.A., \& Cucuzza, T.G. (1995). Tapping the full potential of ABC. Harvard Business Review, 73(4), 130-138.

Scarbrough, P., Nanni, A.J., \& Sakurai, M. (1991). Japanese management accounting practices and the effects of assembly and process automation. Management Accounting Research, 2(1), 27-46. https://doi.org/10.1016/S10445005(91)70025-5

Shank, J.K., \& Govindarajan, V. (1989). Strategic cost analysis: the evolution from managerial to strategic accounting. New York: McGraw-Hill/Irwin.

Shields, M. (1998). Management Accounting Practices in Europe: A Perspective from States. Journal of Management Accounting Research, 9, 501-513. https://doi.org/10.1006/mare.1998.0081

Soin, K., Seal, W., \& Cullen, J. (2002). ABC and organizational change: an institutional perspective. Management Accounting Research, 13(2), 249.271. https://doi.org/10.1006/mare.2002.0186

Spicer, B.H. (1992). The resurgence of cost and management accounting: A review of some recent developments in practice, theories and case research methods. Management Accounting Research, 3(1), 1-37. https://doi.org/10.1016/S1044-5005(92)70001-8

Staubus, G.J. (1990). Activity costing: Twenty years on. Management Accounting Research, 1(4), 249-264. https://doi.org/10.1016/S1044-5005(90)70061-3

Turney, P.B.B. (1991). Common cents: The ABC performance breakthrough: How to succeed with activity-based costing. Hillsboro, Or: Cost Technology.

Wiersma, E. (2009). For which purposes do managers use Balanced Scorecards?: An empirical study. Management Accounting Research, 20(4), 239-251. https://doi.org/10.1016/j.mar.2009.06.001

Zimmerman, J. (2001). Conjectures Regarding Empirical Managerial Accounting Research. Journal of Accounting and Economics, 32, 411-427. https://doi.org/10.1016/S0165-4101(01)00023-4

Intangible Capital, 2018 (www.intangiblecapital.org)

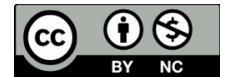

Article's contents are provided on an Attribution-Non Commercial 4.0 Creative commons International License. Readers are allowed to copy, distribute and communicate article's contents, provided the author's and Intangible Capital's names are included. It must not be used for commercial purposes. To see the complete license contents, please visit https://creativecommons.org/licenses/by-nc/4.0/. 